\title{
Proteomic profiles among asymptomatic HTLV-1 carriers and HAM/TSP patients in Peru
}

\author{
Morayma Temoche ${ }^{1,2}$, Jason Rosado ${ }^{1,2}$, Carolina Alvarez ${ }^{2,3}$, Daniel Clark², Eduardo Gotuzzo ${ }^{2,5,6}$, Michael Talledo ${ }^{1,2^{*}}$ \\ From 16th International Conference on Human Retroviruses: HTLV and Related Viruses \\ Montreal, Canada. 26-30 June 2013
}

High proviral loads have been described in HTLV-1associated myelopathy/tropical spastic paraparesis (HAM/TSP) patients in comparison to asymptomatic HTLV-1 carriers (AC). However, biomarkers related to HAM/TSP progression have not been identified. We analyzed differential proteome changes by two-dimensional gel electrophoresis (2D-electrophoresis) to identify spots of proteins in plasma samples of three groups of patients: five $\mathrm{AC}$, nine HAM/TSP patients: five patients with EDSS scores of 1.0-5.0 (=mild HAM/TSP) and 4 patients with EDSS scores of 5.5-9.0 (=severe HAM/TSP). Proteins were extracted from pooled plasma samples from each group of patients. Protein separations were performed by electrofocusing with $11 \mathrm{~cm}$ strips at $3-10 \mathrm{pH}$ range, electrophoresis with $12 \%$ poliacrilamide gel electrophoresis and silver staining. Analyses were performed in Progenesis Same Spot software; ANOVA was used to compare the profiles of the groups. Six spots of proteins were differentially expressed among these groups: five proteins increased their expression according to HAM/ TSP disease progression (highest fold change $=6.1$, $\mathrm{p}=1.671 \times 10-4$; lowest fold change $=1.5, \mathrm{p}=0.014$ ) while one protein was highly expressed in $\mathrm{AC}$ and decreased according to HAM/TSP progression (fold change $=5.8$, $\mathrm{p}=0.002$ ). Further studies to confirm the expression of these proteins in a larger set of samples are still in progress, the identification of these proteins will be performed by mass spectrometry. These results might be promissory to identify biomarkers for HAM/TSP progression.

\section{Authors' details}

'Laboratorio de Epidemiología Molecular, Universidad Peruana Cayetano Heredia, Lima, Peru. ${ }^{2}$ Instituto de Medicina Tropical Alexander von Humboldt, Universidad Peruana Cayetano Heredia, Lima, Peru. ${ }^{3}$ Rega Institute for Medical Research, Katholieke Universiteit Leuven, Leuven, Belgium. ${ }^{4}$ Laboratorios de Investigación y Desarrollo, Universidad Peruana Cayetano Heredia, Lima, Peru. ${ }^{5}$ Facultad de Medicina, Universidad Peruana Cayetano Heredia, Lima, Peru. ${ }^{6}$ Hospital Nacional Cayetano Heredia, Lima, Peru.

Published: 7 January 2014

\section{doi:10.1186/1742-4690-11-S1-P127}

Cite this article as: Temoche et al:: Proteomic profiles among asymptomatic HTLV-1 carriers and HAM/TSP patients in Peru. Retrovirology 2014 11(Suppl 1):P127.

\footnotetext{
* Correspondence: michael.talledo.a@upch.pe

'Laboratorio de Epidemiología Molecular, Universidad Peruana Cayetano Heredia, Lima, Peru

Full list of author information is available at the end of the article
}

Submit your next manuscript to BioMed Central and take full advantage of:

- Convenient online submission

- Thorough peer review

- No space constraints or color figure charges

- Immediate publication on acceptance

- Inclusion in PubMed, CAS, Scopus and Google Scholar

- Research which is freely available for redistribution 